\title{
International linkages, geopolitics, and the Belt and Road Initiative: A comparison of four island territories
}

\author{
Ying-ho Kwong \\ College of Professional and Continuing Education, Hong Kong Polytechnic University \\ yingho.kwong@cpce-polyu.edu.hk (corresponding author)
}

\author{
Mathew Y.H. Wong \\ Education University of Hong Kong, Hong Kong \\ myhwong@eduhk.hk
}

\begin{abstract}
Existing literature has placed a strong emphasis on foreign linkages for the sustainability of island territories. However, studies have largely focused the effect of Western linkages, leaving the rise of Asian linkages unexplored. Such an investigation is of increasing significance given China's rise in global politics and its ambitious Belt and Road Initiative (BRI). This article explains island territories' inclination towards this newfound Chinese influence by comparing two Danish island territories and two Chinese island territories and argues that island territories with strong international linkages tend to face more challenges to accept the BRI, as demonstrated by the cases of Greenland and Hong Kong with stronger US strategic, military, and diplomatic linkages; and vice versa for the Faroe Islands and Macau with relatively weak international linkages. This paper contributes to the literature by moving beyond internal factors, including island types, sizes, and peripheralities, to explore how external factors, namely foreign linkages in international politics, from an alternative geopolitical perspective.
\end{abstract}

Keywords: Belt and Road Initiative, China, economic dependence, geopolitics, islands, United States

https://doi.org/10.24043/isj.127 • Received January 2020, accepted September 2020

(C) 2020 - Institute of Island Studies, University of Prince Edward Island, Canada.

\section{Introduction}

The literature on island politics has long recognized the significance of foreign linkages for island territory sustainability (e.g. Ferdinand, Oostindie \& Veenendaal, 2020; Fish \& Gunther, 1994; Dornan \& Pryke, 2017; Karlsson, 2009). The findings generally indicate that island territories with stronger external linkages are more capable of utilizing existing and new resources in order to actively create external and internal opportunities (Baldacchino \& Milne, 2000; Bueger \& Wivel, 2018). As suggested by Cooper and Shaw (2009, p. 2), island territories in the contemporary age have demonstrated their ability to 'adopt diplomatic practices that involve global networks advancing global governance.' However, the implications 
of international linkages have yet to be thoroughly explored. Studies have traditionally concentrated on the role of international linkages in Western world whilst the impact of Asian linkages is seldom explored. Given the rise of Chinese influence in recent years, the understanding of international linkages should move beyond the traditional Western ones, in particular that of the United States (US), to a new perspective, in particular the 'competition between China and US' (Pöllath, 2018). In this regard, some studies have explored how island territories can select to align with either the US or China internationally or even the possibilities of 'multiple foreign influences' to attain sustainability (e.g. Davis, Munger \& Legacy, 2020).

By examining the spread of Belt and Road Initiative (BRI), a Chinese-led international framework that encourages political, economic, and cultural dependence on China, this study explains island territories' stance towards this emerging Chinese influence by comparing four subnational island jurisdictions (SNIJs). We argue that island territories with strong international linkages tend to face more challenges to accepting the BRI, and vice versa.

A mixed most-similar and most-different cases comparison method is adopted in this paper. Hong Kong and Macau can be considered as two 'Chinese island cities' due to their island spatiality and historical evolution in China's Pearl River Delta (e.g. Sheng, Tang \& Grydehøj 2017; Yuen \& Cheng 2020) and a number of internal similarities, including relatively large population size, near-shore island city types, and proximity to Beijing (Kwong \& Wong, 2017). Critically, however, whereas the population of Macau is broadly supportive of the BRI, there is strong polarization of public opinion concerning the BRI in Hong Kong. Similarly, Greenland and the Faroe Islands are two 'Danish sub-national island jurisdictions' due to their island spatiality and historical connections in the Arctic and North Atlantic (Karlsson 2009) as well as some internal similarities, including relatively small population size, oceanic island type, and proximity to Washington, DC. However, Greenland faces more intervention from its sovereign metropolitan state and even the US in order to discourage its close cooperation with China while this is not the case for the Faroe Islands. Although (a) Hong Kong and Greenland and (b) Macau and the Faroe Islands are characterized by different internal island features, both paired cases demonstrate a similar pattern with regard to international linkages. This paper makes an original contribution by moving beyond the internal islandness of these cases to assess the effects of external factors, in particular in the era of competition between the US and China, from an alternative geopolitical perspective.

This article is organized into five sections. It begins with a review of island politics from an international linkage perspective. Second, it highlights the mixed most-similar and mostdifferent case comparison method. Third, it examines some similarities of internal island features in the two paired cases and then compares their similarities and differences with regard to the BRI. The last section compares the external factors, in particular the US linkages, among all cases.

\section{Island territories and international linkages: From a 'Western' perspective to 'US- China competition' perspective}

The need for island territories to remain dependent on economic contributions from large states for sustainability is recognized in the literature on island politics (Grydehøj, 2020c; Campling, 2006; Armstrong \& Read, 2000). However, most studies in this tradition have 
focused on island internal factors, including island sizes, island types, and peripheralities. From this perspective, whether an island territory can achieve sustainability depends on distinct island attributes. First, small island territories tend to face more economic challenges than large ones due to the small size of the domestic market, small scales of production, and limited development of technologies and infrastructure (Prasad, 2003; Armstrong \& Read, 2003). Second, near-shore island cities tend to face fewer economic challenges than oceanic islands because of the concentration of political and economic elites and the sufficiency of labor forces (Grydehøj, 2015). Third, island territories with close proximity to large states tend to face fewer economic challenges than those with long distance, due to the geographical advantages in creating business opportunities (Baldacchino, 2020; Amoamo, 2013). Important though these internal perspectives are, they arguably do not provide a complete picture without also considering external factors.

In response to this gap, a number of studies have studied the concept of 'islandness' in terms of international linkages. Islandness, in this paper, is defined as the characteristic that distinguishes island territories geographically, constitutionally, culturally, and politically from mainland territories (Penrose, 2002), bearing in mind that attributes of islandness are highly diverse and not applicable to all types of islands (Grydehøj, 2020a). Apart from relying on an 'internal' mainland, scholars are interested in exploring how island territories build external linkages with major countries in order to maximize their influence and achieve sustainability (e.g. Bueger \& Wivel, 2018; Veenendaal, 2017). On the one hand, some island territories which are weak, exposed, and vulnerable in economic terms (e.g. small domestic markets), security conditions (lack of military resources), or global reputation tend to be more active in connecting with the globalizing world economy (Lee \& Smith, 2010). On the other hand, large states, especially leading global powers, would provide economic aid or assistance, trading opportunities, military presence, or even consumption quotas in return for connections (Levine, 2012; Grydehøj, 2020c). Alberti and Goujon (2020) argue that diplomatic networks, defined as the 'capacity to enter into relations with other states' are still an important dimension for understanding island territories' autonomy.

However, this is only one side of the story. It is obvious that island territories and large states are mostly 'in an asymmetric relationship' (Oest \& Wivel, 2010, p. 434). As suggested by Jesse and Dreyer (2016, p. 3), 'the great powers establish not only the norms and structures of the international system, but also the regional security hierarchies.' Although island territories are active in gaining 'recognition' from other countries, the key factor in determining island territories' success is their ability to be 'recognized' by large states, and however active island territories may be in seeking such recognition, large states are themselves driven economic (e.g. natural resources and business opportunities), security (geographical locations for military arrangement), and diplomatic (leverage in international and regional organizations) considerations (Levine, 2012).

Indeed, the mainstream discourse of international linkages is dominated by and unitary to the Western world, given its traditional significance as the geopolitical center in international influence and domination. One pioneering work is from Bertram and Watters (1985), which examines how small islands adopted, by circumstance and by design, migrationremittances-aid-bureaucracy (MIRAB) strategies in relation to New Zealand. Within the context of island politics, a geopolitical center is defined as a geographical core of gravity weighing heavily upon the development path of the island territory given its location. 
Historically speaking, the US and European Union as a geopolitical center have been the only focus for decades. While some scholars such as Pöllath (2018) describe the US as 'US hegemony,' 'international linkages' are synonymous with links with the US and European countries with an almost dominating power in the recognition of small territories. However, international linkages from Asian world were seldom explored until the recent emergence of the BRI.

In response to the recent rise of China in global politics, the study of international linkages should move beyond a purely Western perspective to a competition perspective focusing on the competition between China and the US. Since Xi Jinping, the President of People's Republic of China, assumed power in 2012, Beijing has taken the initiative to encourage regional economic cooperation, military development, and diplomatic coordination, especially among island territories. In this connection, China's BRI can be understood as a geopolitical strategy (Ferdinand, 2016). However, in common with the literature on island politics reviewed above, most studies focus on the political influence of Western countries whilst relatively little is known about China's countering influence (Bader, 2015; Wong, 2019). It is suggested that China has targeted many island territories through infrastructure, military, and diplomatic interests to decrease their dependence on the US. The competition between polarized global powers has become an important topic for island territory sustainability.

\section{Research methods: Mixed most-different and most-similar cases comparison}

To study the contrasting interests among island territories, this paper focuses on four cases and adopts a mixed most-different and most-similar case selection method for analysis. The mostsimilar method employs a minimum of two cases similar on the measured independent variables with different outcomes on their dependent variables (Seawright \& Gerring, 2008). It emphasizes the 'method of difference,' which looks for 'antecedent conditions that differ between two cases that have different outcomes' (Bennett 2012, p. 31). Most-different method, in contrast, employs at least two cases that are most different but with similar outcomes of dependent variables (Seawright \& Gerring, 2008). It emphasizes the 'method of agreement,' which explores cases with different features but with similar outcomes. Both methods aim to be broadly representative of the cases and provide a strong basis for generalization. Although these two methods seem to be conflicting selection techniques, it is important to recognize that many case studies also mix and match their strategies. As argued by Anckar (2008, p. 400), the biggest advantage to mixed methods is 'to eliminate a large number of potentially relevant explanatory variables from further analysis.'

In addition to this methodological consideration, case selection is based on three reasons: First, in terms cultural background, the Faroe Islands and Greenland are chosen for their European background with close connection with Western world, though it is important to note that Greenland possesses a non-Western Indigenous culture and was historically a colonized territory. These two cases provide a nice complement to Hong Kong and Macau, with close connections with China and other Asian countries. Second, as far as China is concerned, given that Hong Kong and Macau are Special Administrative Regions (SARs) under Chinese sovereignty, both island territories are considered essential platforms for connecting China with other regions. Since 2013, the Chinese government has 
increasingly engaged in the Arctic region, with Greenland and the Faroe Islands emerging as new and significant targets. Third, as far as the US is concerned, the US government has more geopolitical interest in Hong Kong than in Macau and more in Greenland than in the Faroe Islands. It is argued that this set of comparisons allows for a good generalization of our argument by demonstrating that it is not limited to a certain pair or geographical area. This study analyzes four cases in three stages: Stage one is to examine the similarity of island types within these two pairs of cases. The second stage is to compare the different outcomes of the four cases, in terms of their acceptance of the BRI. The final stage explores the US's strategic interests in these cases as explanatory factors.

\section{Similarities regarding islandness}

Island studies literature has long debated on the concepts of 'islandness' and 'insularity'. 'Insularity' has been defined as a 'a set of tensions and ambiguities, opportunities and constraints arising from the interplay of geography and history' (Wattington \& Milne, 2007, p. 383). Under this approach, geographical characteristics and historical development are the key concerns to assert a distinction between island and mainland territories. However, as pointed out by Hay (2006), these two factors are not the key driving force for differentiating islands, which is instead 'physical boundedness.' Indeed, 'physical factors' are conducive to 'psychological distinctiveness,' which has ultimately contributed to building 'bounded identities' within social, cultural and political contexts. For this reason, scholars have extended their studies to include the concept of 'islandness', which emphasizes a comprehensive approach and facilitates characterizations of what makes islands distinctive. Islandness refers to the specific qualities of island territories, combining both physical and psychological factors to distinguish island from mainland (Jackson, 2008). Islandness can be used to study the dynamics of geographical boundaries, historical connections, constitutionalisms, cultural identities, and political autonomies (Penrose, 2002; Corbett, 2020). This approach is adopted to compare islandness among the four selected island territories.

\section{Hong Kong and Macau}

Before Hong Kong and Macau became SARs of China, they had similar colonial experiences: Macau became a Portuguese colony in 1558 and Hong Kong a British colony in 1842. The Sino-British Declaration in 1984 and the Sino-Portuguese Declaration in 1987 stipulated the transfer of sovereignty from both colonial powers to China under the principles of 'one country, two systems'. Constitutionally, both SARs are governed by the Basic Laws, their de facto constitutions under the Constitution of China, and were intended to possess a high degree of autonomy except in military and diplomatic affairs. The two Declarations also set forth that the SARs would be governed by their local populations alone. Culturally, Cantonese is the first language for $80.1 \%$ and $88.8 \%$ of the populations of Macau and Hong Kong respectively while Putonghua is the first language in mainland China. Politically, as in the colonial period, the governments of both SARs have maintained hybrid status with limited electoral rights and some civil liberties (Kwong \& Wong, 2017). Currently, half of the seats $(50 \%, 35$ out of 70 seats) in the legislature of Hong Kong and fewer than half $(42.4 \%$, 14 out of 33 seats) of the legislature in Macau are filled by direct elections. The Chief Executives, the heads of the SARs, are handpicked by the Election Committees (400 
members in Macau, who are elected by around 5,700 organization voters, and 1,200 members in Hong Kong, who are elected by some 246,000 individual and organization/company voters), which are open to influence by the Chinese government (Fong, 2013).

With an area of $1106.7 \mathrm{~km}^{2}$, Hong Kong is comprised of Hong Kong Island, the Kowloon Peninsula, and the New Territories (which includes numerous islands), whilst Macau's $32.9 \mathrm{~km}^{2}$ is comprised of the Macau Peninsula and the islands of Coloane and Taipa. Currently, Hong Kong hosts a population of 7,451,000 while Macau has a population of 667,400 . The population density of Hong Kong is around 6,700 people $/ \mathrm{km}^{2}$ while that of Macau is around 20,300 people $/ \mathrm{km}^{2}$. Although smallness is not easily defined, this paper adopts the most widely used definition in terms of population size: microstates have populations under 100,000, small states have populations under 1.5 million, and large states have populations over 5 million (Peterson, 2006). For the purpose of this study, Hong Kong can be classified as a relatively large territory while Macau should be regarded as a small territory. As for island type, Hong Kong and Macau are island cities located in China's Pearl River Delta, which also contains numerous distinct neighboring, including Guangzhou and Shenzhen (Grydehøj, 2015). These two island cities are located on the coast of southern China, the economic center of Asia, but are distant from the Western economic center. As a result, Hong Kong and Macau can be regarded as 'Chinese island cities' due to their island spatiality, history, and political development (Kwong \& Wong, 2017; Yuen \& Cheng, 2020).

\section{Greenland and the Faroe Islands}

Greenland and the Faroe Islands are self-governing territories of the Danish Realm with extensive autonomous powers and responsibilities. Greenland became a colony of DenmarkNorway in the $18^{\text {th }}$ Century and transitioned into a Danish county in 1953 . The Faroe Islands were officially administrated as a Danish county from 1814 but received Home Rule in 1948 and then Self-Government in 2005. Greenland achieved Home Rule in 1979 and SelfGovernment in 2009, as a result of referenda and negotiations with Denmark. Greenland and the Faroe Islands have become autonomous regions of Denmark with legislative and executive power regarding self-ruled matters, except in military, diplomatic, and specialist legal areas. Foreign policy is still dominated by the Danish sovereign state. The Greenlandic parliament (Inatsisartut) and Faroese parliament (Løgting) are governing bodies elected by the residents of the respective island territories alone, without interference from Denmark. Culturally, Faroese is the first language in the Faroe Islands and Greenlandic is the first language in Greenland while Danish is the second language in both territories. The governments of both Greenland and the Faroe Islands are formed within a multiparty parliamentary system. Currently, all 31 members of Parliament in Greenland and all 33 members in Parliament in the Faroe Islands are elected by all inhabitants. Together with the protection of civil liberties, both Greenland and the Faroe Islands can be considered democratic regimes (Gad, 2017; McBride, 2019), though it is noteworthy that the government of Greenland has been led by the same party for all but four years since the introduction of Home Rule in 1979 (Grydehøj, 2020b).

Geographically, Greenland is the largest island in the world with a land mass of 410,449 $\mathrm{km}^{2}$ with five municipalities whilst the Faroe Islands' $1,399 \mathrm{~km}^{2}$ is comprised of 18 islands, divided into 29 municipalities. Greenland's population is 55,992 $\left(0.14\right.$ people $\left./ \mathrm{km}^{2}\right)$ whereas the Faroe Islands' population is $50,750\left(36.28\right.$ people $\left./ \mathrm{km}^{2}\right)$. Based on the above classification, 
both Greenland and the Faroe Islands should be regarded as microstates (population less than 100,000). As for island type, Greenland and the Faroe Islands are oceanic islands located in the West Nordic Region, which are highly archipelagic with widely dispersed settlement areas (McBride, 2019). These two oceanic island territories are peripheral to Denmark but are located relatively close to the Western economic center and far away from the Asian economic center. Overall, Greenland and the Faroe Islands can be regarded as Danish subnational island jurisdictions with respect to their island spatiality, history, and political backgrounds (Karlsson 2009). Table 1 summarizes the island sizes, types, and positions of the four cases.

Table 1. Comparison between Hong Kong, Macau, Greenland and the Faroe Islands.

\begin{tabular}{|c|c|c|c|c|}
\hline & Hong Kong & Macau & Greenland & Faroe \\
\hline Population & $\begin{array}{c}\text { 7,451,000 } \\
\text { (large state) }\end{array}$ & $\begin{array}{c}667,400 \\
\text { (small state) }\end{array}$ & $\begin{array}{c}55,992 \\
\text { (microstate) }\end{array}$ & $\begin{array}{c}50,750 \\
\text { (microstate) }\end{array}$ \\
\hline Land area $\left(\mathrm{km}^{2}\right)$ & $1,106.7$ & 32.9 & 410,449 & 1,399 \\
\hline $\begin{array}{l}\text { Population density } \\
\left(\text { people } / \mathrm{km}^{2}\right)\end{array}$ & 6732.6 & 20285.7 & 0.14 & 36.28 \\
\hline Island type & Island city & Island city & Oceanic island & Oceanic island \\
\hline $\begin{array}{l}\text { Distance from } \\
\text { Beijing }(\mathrm{km})\end{array}$ & 1,987 & 2,008 & 8,398 & 7,320 \\
\hline $\begin{array}{l}\text { Distance from } \\
\text { Washington }(\mathrm{km})\end{array}$ & 13,122 & 13,145 & 3,279 & 5,266 \\
\hline
\end{tabular}

Sources: Census and Statistics Department of Hong Kong (2019), Macau Statistics and Census Services (2019), Statistics Greenland (2019), Faroe Islands.FO (2019); For distance from Beijing and Washington, the data is calculated by 'Air Miles Calculator' (https://www.airmilescalculator.com/).

\section{The BRI as a Chinese incorporation strategy: Different outcomes}

When the Chinese government announced the BRI in 2013, its intention to expand its regional and global influences was most apparent. The BRI aims to promote China's soft power by developing infrastructure projects and strengthening Chinese economic connections beyond China's existing sphere of influence (Liu \& Lim, 2018; Yu, 2017). The ultimate objective is to weaken the participating territories' dependence on the US and European powers and strengthen their infrastructural, political, and economic dependence on China (Tekdal, 2018). The BRI has further served as a means of focusing policy attention on many island cities and sparsely populated and peripheral small islands. However, the BRI's role as a counterweight against US influence receives very different receptions depending on the internal and external factors at play in particular island societies.

\section{Embracing China with diversified outcomes: Macau and Hong Kong}

Under 'one country, two systems', both Hong Kong and Macau retain their own economic, social, and legal systems which are important elements under the BRI framework from the Chinese perspective (Xinhua, 2017, March 16). Hong Kong has long been an international finance and logistics center as a facilitator of connections between China and Western, mainly 
English-speaking, regions. With a colonial history with Portugal, Macau is mainly used as the middleman to strengthen China's connections with Portuguese-speaking regions. As parts of China, government officials in both Hong Kong and Macau have demonstrated active participation in the BRI. In 2017, the HKSAR government signed the 'Arrangement between the National Development and Reform Commission and the Government of the HKSAR for Advancing Hong Kong's Full Participation in and Contribution to the BRI'. The document demonstrates Hong Kong's contributions to the BRI in finance and investment, economic and trade facilitation, people-to-people bonds, and enhancing collaboration in dispute resolution (Belt and Road Initiative - Hong Kong, 2019). The government of Macau signed a similar agreement in 2018 (Macau SAR Government, 2019), indicating how Macau can contribute to the BRI, including by building economic and cultural collaboration with Portuguese regions. A Joint Conference mechanism has been set up in the two SARs as a regular and direct communication platform for BRI affairs. In particular, the HKSAR government and Ministry of Commerce established a 'Mainland and Hong Kong BRI Task Group' in 2018 to coordinate BRI-related matters in trade and economic cooperation.

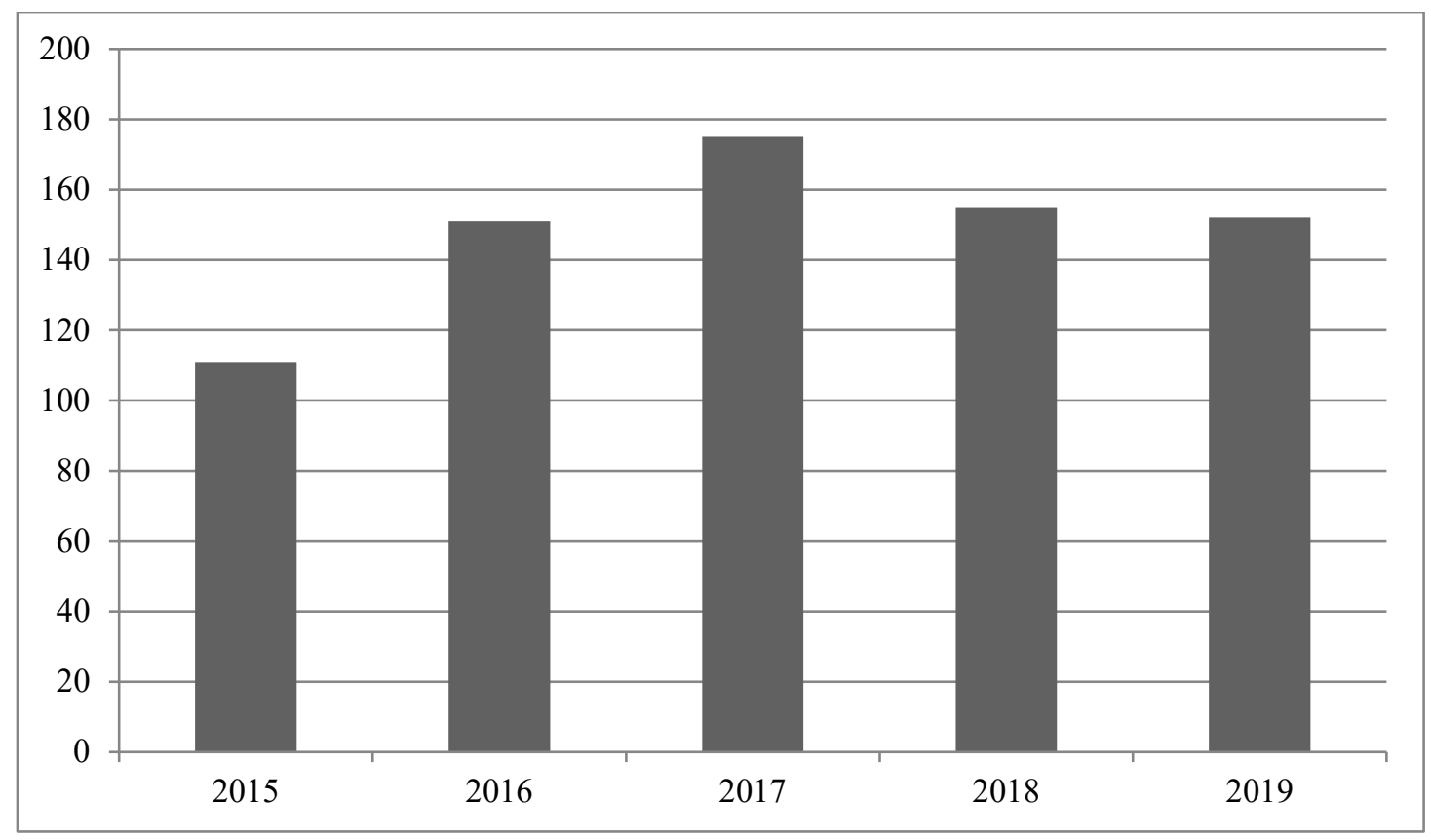

Figure 1. Number of public events by pro-China organizations promoting BRI in Hong Kong, 2015-2019. Source: Authors' content analysis of three pro-Beijing newspapers (Hong Kong Commercial Daily, Ta Kung Po and Wen Wei Po) through Wisenews search engine, a Chinese newspaper data set, and identification of related events. Relevant events $=(1)$ organizing sharing sessions with their members, (2) holding or participating in forums with other organizations, and (3) attending conferences outside the territory. 


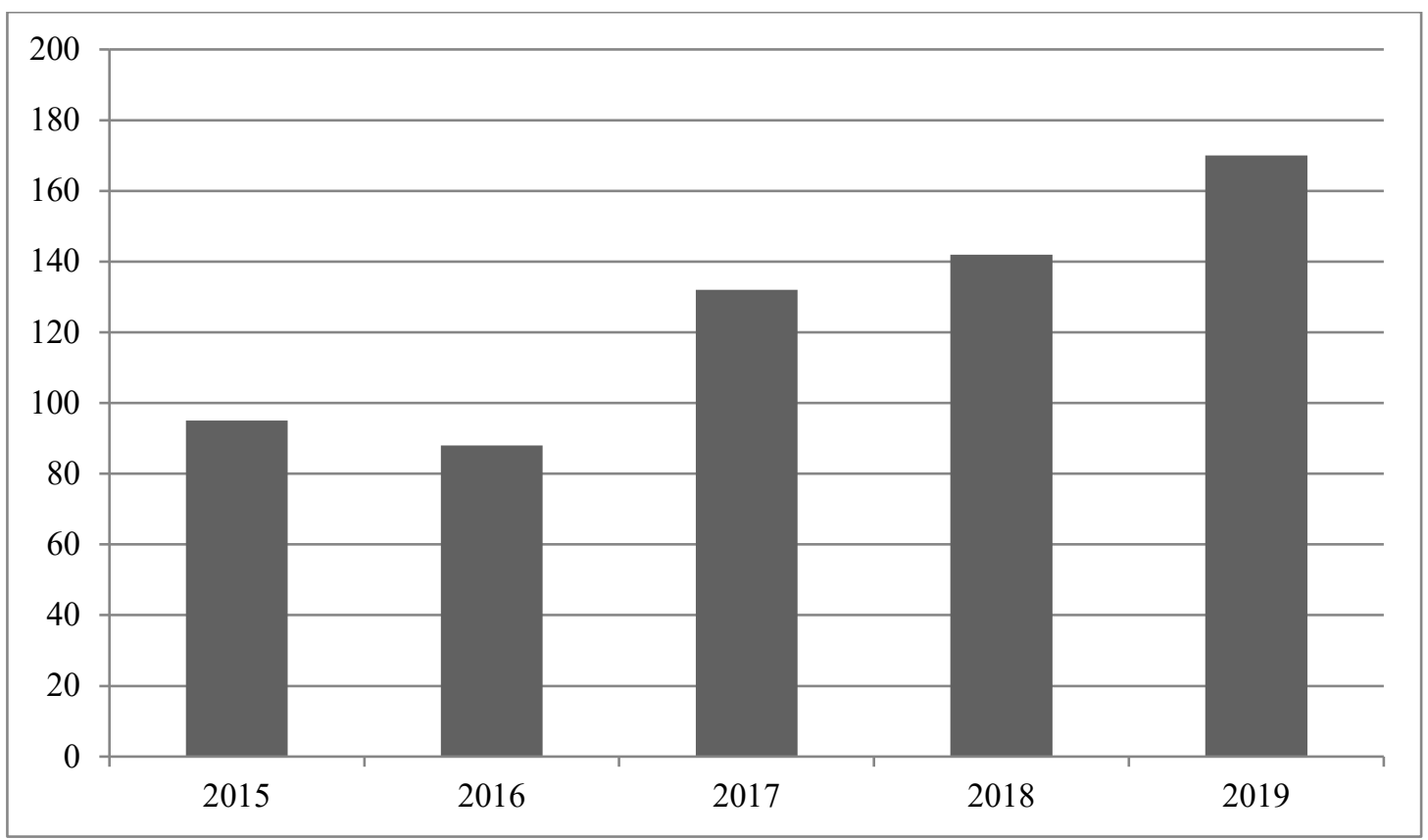

Figure 2. Number of public events by pro-China organizations promoting BRI in Macau, 2015-2019. Source: Authors' content analysis of three pro-Beijing newspapers (Hou Kong Daily, Jornal San Wa Ou, and Macao Daily News) through Wisenews search engine, a Chinese newspaper data set, and identification of the related events. Relevant events $=(1)$ organizing sharing sessions with their members, (2) holding or participating in forums with other organizations, and (3) attending conferences outside the territory.

In line with the official strategies, local pro-China organizations, such as political parties, chambers of commerce, townsmen associations, labor unions, and youth organizations, which promote ties between Hong Kong/Macau and China have mobilized to promote the BRI to people in both SARs. The key priority is to promote the new business and working opportunities brought about by the BRI and then to encourage participation and contribution to this ambitious project. Figures 1 and 2 show that such associations in Hong Kong and Macau are quite active in hosting or participating in public events. On average, Hong Kong records around 149 events annually while the number of events in Macau has gradually increased from around 95 in 2015 to more than 170 in 2019. In general, the patterns between Hong Kong and Macau are quite similar, with supportive organizations actively engaging in the delivery of the BRI. Apart from public events, some new organizations have been established in the name of the BRI to facilitate the collaboration. For example, the 'Maritime Silk Road Society', 'Belt and Road General Chamber of Commerce', and 'Field Trips of BRI' were established in Hong Kong to coordinate economic, cultural and youth involvement in the BRI. Similarly, 'Macau Association of the Belt and Road Higher Education Interchange', 'Belt and Road National Education Promotion Macau Association', and 'Mainland China-Macau Belt and Road Business and Professional Service Council' were established in Macau.

Both government officials and pro-China associations in both SARs took the lead in increasing people's economic dependence on China through the BRI, but two rather different political consequences have been observed: despite repeated promotion of the economic benefits associated with the BRI, the public in Hong Kong is significantly more negative 
about the future of China in Hong Kong than is the case for the public in Macau in terms of the future of China in Macau. Figures 3 and 4 present the net values of confidence (the percentage of respondents who have confidence, subtracted by those who do not have confidence) in China's future in Hong Kong and Macau respectively. According to a recent representative survey by the University of Hong Kong Public Opinion Programme, a net $-2 \%$ of respondents in Hong Kong indicate that they are confident. Although the figures have fluctuated, the overall trend of confidence has decreased even after the announcement of the BRI in 2013 while the pattern of 'not confident' has increased. Based on the same survey conducted in Macau, however, the general trend is steady and highly positive. Macau residents demonstrated a net confidence of around $+70 \%$. People who are confident stayed at around $80 \%$ while the figure for 'not confident' remained very low, at around $10 \%$. Based on these figures, Hong Kong people are much more split about China's future than are their counterparts Macau, especially after the outbreak of protests against the extradition bill in June 2019.

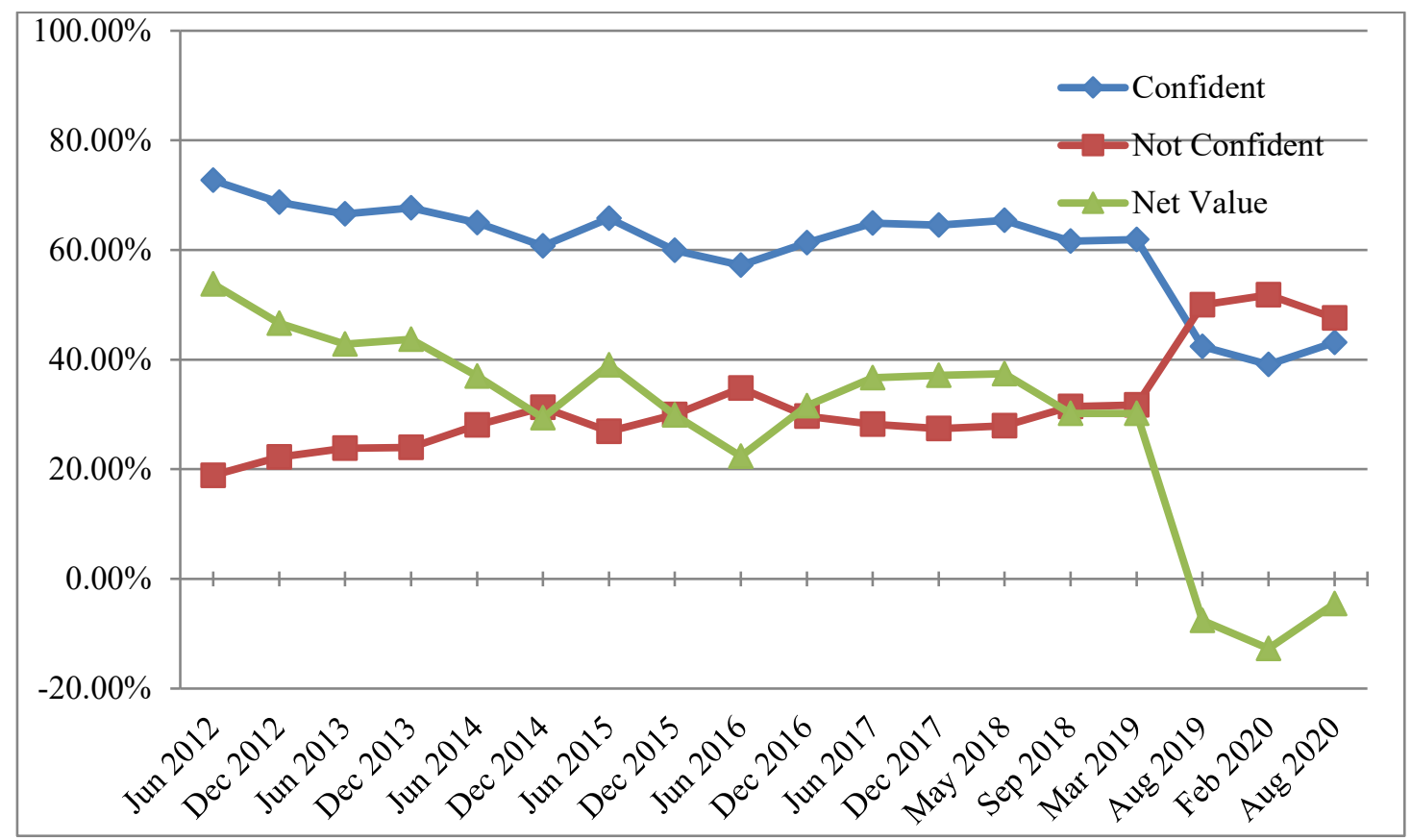

Figure 3. Hong Kong people's confidence in China's Future. Source: HKUPOP (2019a). 


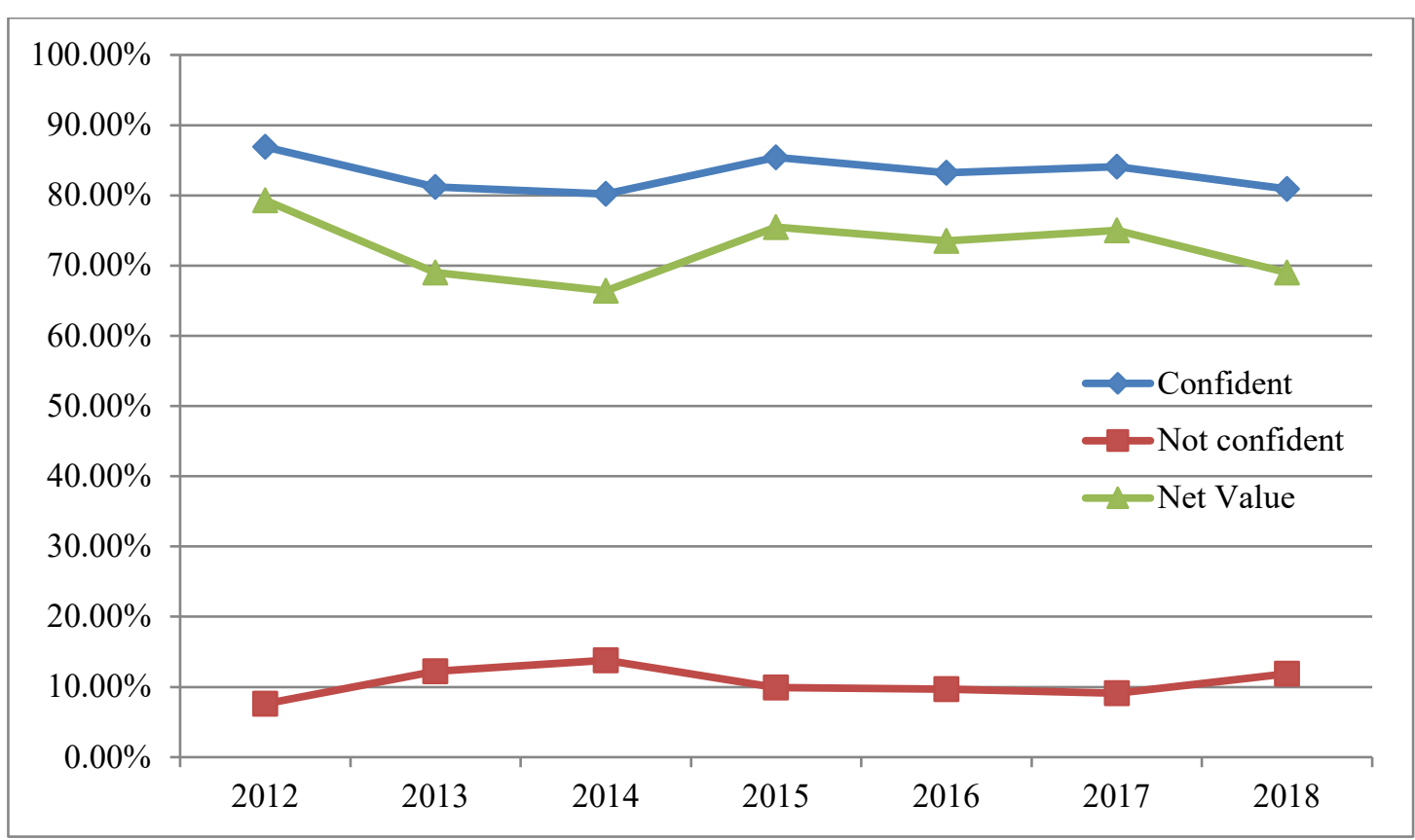

Figure 4. Macau people's confidence in China's future. Source: HKUPOP (2019b).

The split in public opinion regarding the BRI in Hong Kong can be directly demonstrated by other findings. When respondents were asked in 2016 for their response to the involvement of the Hong Kong government in the BRI, 35.3\% did not support the government allocating more resources for projects on the BRI (relative to (against 31\% who did support the government allocating more resources), while $47.9 \%$ of respondents disagreed with the government giving higher priority to BRI projects (versus $15.7 \%$ who agreed that the government should give BRI projects higher priority) (Table 2).

Table 2. Hong Kong residents' responses to increasing Hong Kong government involvement in the BRI. Source: Hong Kong Institute of Asia-Pacific Studies (2016).

Q: Do you support the government to allocate more resources for projects related to the BRI? $(\mathrm{N}=712)$

\begin{tabular}{lc}
\hline Support & $31.0 \%$ \\
In-between & $26.7 \%$ \\
Do not support & $35.3 \%$ \\
\hline Q: Do you agree the government should give a higher priority to projects related to \\
the BRI? (N=712) \\
\hline Agree & $15.7 \%$ \\
In-between & $29.4 \%$ \\
Disagree & $47.9 \%$ \\
\hline
\end{tabular}

Hong Kong people's polarized attitudes towards the BRI has political origins, emerging out of the development of 'anti-China' sentiments in earlier years (Ma, 2015), the failure of the Umbrella Movement to extract any concessions from China regarding political development in 2014 (Kwong, 2016), and protests against the extradition bill in 2019 (Lee, Yuen, Tang, \& Cheng, 2019). As an increasing number of people have developed strongly negative views of the Chinese government, this dissatisfaction may spread to policy initiatives 
originating in China. Although the government and pro-China associations continuously promote the BRI, the community is polarized in its views of China and, consequently, of the BRI. In other words, no consensus can be found in Hong Kong.

In comparison, such political controversies have been largely absent in Macau. Given the similar characteristics of the two SARs, the divergent outcomes are puzzling. It can nevertheless be concluded that government officials and pro-China groups in both SARs have a positive attitude towards the BRI, but whereas the people of Macau are overwhelmingly positive about the BRI, public opinion in Hong Kong is much more split, with many people having negative opinions of the BRI.

\section{Embracing China with diversified outcomes: the Faroe Islands and Greenland}

Both the Faroe Islands and Greenland are self-governing island territories of Denmark, and both have developed strong political independence movements. In the Faroe Islands, support for political independence has remained around 50\% (Adler-Nissen, 2014) while in Greenland support for independence has remained steadily around 67\% (Grydehøj, 2020b), showing little confidence in Denmark's future role in these territories. The key concern for many people is whether the island territory can be financially sustainable as the budget for Greenland's government still relies on an annual grant from Denmark (Grydehøj, 2020c). Both the Faroese and Greenlandic governments are searching opportunities to enhance their economic self-sustainability and reduce their financial reliance on Denmark. As a result, they are seeking to create economic links with other states, especially the US and China. China's advocacy of the BRI can be considered a golden opportunity for building better connections with foreign states. However, the outcomes of the two island territories are different even though both have a broadly pro-BRI stance.

Since the unveiling of the BRI blueprint in 2013, the Chinese government has had a targeted engagement in the Arctic region, initially through scientific interactions and later through economic collaboration and infrastructure investments. In 2017, the National Development and Reform Commission of China officially announced that the Arctic Ocean would be incorporated within its list of 'blue economic corridors' as a major part of the BRI. The engagement policy was further codified in the first governmental White Paper on the Arctic in 2018, which advocates the creation of a 'Polar Silk Road' (Blaxekær, Lanteign, \& Shi, 2018). In May 2019, the Arctic Circle China Forum hosted by the Ministry of Natural Resources of China was held in Shanghai to discuss China's involvement in the Arctic on science and innovation, transport, and infrastructure within the BRI framework. Over the past few years, China has launched a series of industrial, scientific, and technological cooperation activities in the Nordic region in order to strengthen its diplomatic position visà-vis the US's diplomatic position. On the one hand, through the BRI, China is becoming a preferred partner, which creates a myriad of new opportunities for some Nordic countries and territories (Tillman, Jian, \& Nielsson, 2018). On the other hand, some Nordic countries and territories consider the extension of China's influence a threat to security, environment, and welfare, making China not a preferable partner after all (Gad et al, 2018).

Indeed, the announcement of the BRI has facilitated China's trade relations with the Faroe Islands since 2017. China is the Faroe Islands' seventh-largest trading partner, after Denmark, Russia, Germany, Norway, United Kingdom, and the US (Blaxekær, Lanteign, \& Shi, 2018). Particularly in terms of fisheries, the key export industry of the Faroe Islands, 
China ranks second (after Russia), importing 12.1\% of fishery products according to recent data (Statistics Faroe Islands, 2019). More than 90\% of the Faroe Islands' export is from fisheries, including salmon and mackerel. After 2010, the export of salmon was increasingly purchased by China. The Chinese government started slowing its import of fish from Norway in response to the awarding of the Nobel Peace Prize to Liu Xiaobo (Satarino, 2019, December 21). Such an increase has been supported by more frequent interactions between China and the Faroe Islands. In 2012, the Chinese government sent a delegation to the Faroe Islands in order to increase imports of fish products and communicate on issues of food safety and regulations. Also, the Faroese government sent a delegation to China consisting of a wide range of companies to visit the health authorities and attend the China Fisheries and Sea Food Expo. The Faroe Islands have largely maintained a cooperative and harmonious relation with China while they generally welcome the new opportunities brought by the BRI.

The most evident case is the acceptance of Huawei, the Chinese telecommunications company, as the key developer of telecommunications infrastructure in the Faroe Islands. In 2014, the Faroese government decided to extend and develop a comprehensive mobile phone infrastructure and launched an international tender with bids from American, European, and Chinese companies. Huawei was finally chosen as strategic partner to develop its $4 \mathrm{G}$ technology while the Chinese communications giant came to be embroiled in a high-profile controversy about the cyber-security and data privacy of its technology. While the US and its allies have gradually been considering banning Huawei from development projects in their own countries due to these growing concerns, the Faroese government has allowed the project to go ahead despite the potential threats (Blaxekær, Lanteign, \& Shi 2018). The Faroe Islands is currently a battlefield between China and the West on the service provision of Huawei. At the time of writing, debates on the development of a $5 \mathrm{G}$ network in the Faroe Islands continue. The Faroese government has emphasized that 'the government has not been pressured or threatened by foreign authorities in relation to the development of a $5 \mathrm{G}$ network. The decision about providers of $5 \mathrm{G}$ equipment and technology lies with the Faroese telecommunications companies' (Fullerton, 2019, December 11).

Greenland is an island territory that faces more challenges when it comes to accepting the BRI. Comparatively speaking, Greenland is strategically valuable from a Chinese perspective. The Chinese government has developed various interests in Greenland, in particular in the areas of scientific research and future exploitation of mineral resources. With most of its land covered by ice and glaciers, Greenland is considered a prime resource of mineral wealth for when ice sheets due to rising temperatures under climate change. The Chinese government and its state-owned enterprises have been active in the island's emerging mining sector. Two leading mineral exploration projects include (1) rare earth element, primarily driven by China's interest in the strategic resource itself, and (2) Citronen Fjord Zinc, which is linked to Chinese foreign policy priorities with a focus on BRI countries (Andersson, Zeuthen, \& Kalvig, 2018). Alongside Australia, China is the big international player in Greenland mining. China Nuclear Hua Sheng Mining is the joint venture that plays a key role in Greenland's potentially most profitable mining project at Kvanefield. It is with these strategic resources in mind that China approaches Greenland with a focus on a mutually beneficial partnership.

The Greenlandic government welcomes new economic activities and aims to be involved in BRI projects. In 2017, Greenlandic government sent a delegation to China which sought greater Chinese involvement in their island economy. The delegation was led by Kim 
Kielsen, the Primer of Greenland, who encouraged more economic cooperation with China in order to enhance Greenland's development. The Greenlandic government also involved China in discussion regarding infrastructure development, particularly for the island's new airports. The officials had a strong desire for the BRI whereas it is believable that this economic cooperation can bring new opportunities for Greenland for relying less on Denmark.

However, the Danish government showed strong opposition to this plan in the name of national security. In an improvement project of a number of existing airports in 2018, six potential contractors, including a Dutch company, a Canadian company, a joint IcelandDanish company, two Danish companies, and a Chinese company, China Communication Construction Company, were placed on the shortlist for the work. However, the Danish government showed a strong disapproval with the involvement of Chinese state-led company and threatened that working visas of Chinese-led companies may be denied which forced the Chinese company to drop out. In June 2018, the governments of Denmark and Greenland negotiated on the financial support for the airport projects from Denmark. From Danish perspective, they aimed to demonstrate an implicit discouragement of Chinese investment. But from a Greenlandic perspective, the agreement was not seen as affecting the potential for future cooperation with China (Grydehøj, 2020c). In September 2018, the Danish and Greenlandic governments signed an agreement that the Danish government would supply 450 million Danish kroner in funds for the project and access to supplementary loans. After that, the US showed its interest in 'strategic investments' in Greenlandic airports by highlighting the geopolitical importance of Greenland and warned about China's involvement (Blaxekær, Lanteign, \& Shi 2018). Some politicians in Greenland saw the opportunity to leverage the competition between the US and China to become more politically independent from other territories, securing economic support, and pursuing their own foreign policy (Grydehøj, 2020c).

\section{US linkages from a geopolitical perspective: Explanatory factors}

From the above analysis, it seems safe to argue that islandness, even with similar and different sizes, types, and geographical positions, is insufficient for explaining how territories relate to the BRI. During the era of competition between the US and China, this study further proposes that the traditional US linkages (and correspondingly, weaker Chinese ones) can be key factors for explaining island sustainability from a geopolitical perspective.

In accordance with this approach, island territories remain economically dependent on large states for survival, and the rise of the BRI creates new opportunities for island territories to build global connections with large states. However, we argue that whether an island territory endorses further dependence on China is determined in large part by the interests of the US, the traditional superpower. The argument is that island territories that are geopolitically important for the US (in our cases, Hong Kong and Greenland) tend to face more challenges when it comes accepting the BRI. In the case of Hong Kong, with strong international linkages, some people believe that China is not the only option for the island territory's survival, which results in more criticism of and conflicts with the pro-BRI officials. Indeed, some may even think of the US government as a reliable partner (Garret, 2014). Since the Danish government still controls foreign policy in both Greenland and the Faroe Islands, the metropolitan sovereign state can determine their external connections in the 
context of US-China great power competition. In Greenland, the Danish government has showed strong hostility to the potential for huge Chinese investment in the key mining sector while the US is ramping up its own expressions of geopolitical interest. This makes it more difficult for Greenland to accept the BRI. However, with relatively limited US linkages, the BRI becomes a genuine option for Macau and the Faroe Islands to connect with foreign states, so they tend to be more welcoming towards the new opportunities. In the following sections, US interests in these island territories are comparatively examined across three dimensions: (1) economic interests, (2) military interests and (3) diplomatic interests.

\section{Economic interests}

Subsequent to the confirmation that Hong Kong and Macau would become Chinese SARs, the US has established different interests in two island cities. In light of its strategic consideration of China as a key competitor, the US enacted the US-Hong Kong Policy Act in 1992, which considered Hong Kong as a separate customs territory from China (US Congress, 1992), allowing itself to continuously develop a deeper economic interest in Hong Kong. Over the years, the US has maintained Hong Kong's access to 'sensitive technologies' under this Act (Article 5713.8). The US is Hong Kong's second-largest merchandise trading partner whilst Hong Kong is the US's tenth-largest export market. The US enjoys the largest trade surplus with Hong Kong, valued at US\$33.8 billion in 2018 alone (HKSAR Government, 2019). In November 2019, amidst increasing concerns about Chinese interference in Hong Kong affairs, the US enacted the Hong Kong Human Rights and Democracy Act to regularly assess Hong Kong's autonomous status. In Macau, the US government has long recognized Macau as a base with strong Beijing connections after the 12-3 Incidents in 1966 (Hook \& Neves, 2002). In 2000, the US enacted the US-Macau Policy Act. Although the title of the legislation is similar to that concerning Hong Kong, the Macau's version establishes export controls by stating that 'US export control laws, regulations, and practices shall apply to Macau in the same manner and to the same extent that they apply to the PRC' (US Department of State, 2004, Article 2, Section B). The US thus expresses different interests in and orientations towards the two island cities, resulting in differential treatment.

As far as Greenland is concerned, the US routinely conducts a wide range of scientific research and pursues the possibility of energy governance in partnership with Danish and Greenlandic institutions. Bearing in mind Greenland's rich mineral resources, the US and Danish governments have been actively involved in resource extraction and investment (Gad, 2013). In 1945, the US government attempted to buy Greenland from Denmark, but the latter was not interested. In August 2019, Donald Trump, the President of the US, raised the possibility of purchasing Greenland (Inman, 2019, August 19). Although the idea was quickly dismissed by both the Danish and Greenlandic governments, it is obvious that the 'resourcefulness of land' in Greenland is attractive from a US perspective. In contrast, the Faroe Islands possess limited land and mineral resources so the US's interests are relatively weak. Over the years, US Ambassadors to Denmark and embassy staff have made numerous visits to the Faroe Islands without any substantial actions as a result (US Embassy in Denmark, 2019).

\section{Military interests}

Since its British colonial days, the US has seen Hong Kong as a reliable and desirable western Pacific free port for supplying the navy, while the location of Hong Kong is geographically 
convenient for traveling to Asian and African destinations. US Navy ships usually visit Hong Kong every year, and it was reported that around 70 US warships visited Hong Kong annually during the British colonial era. However, the number of US Navy visits have evidently decreased after Hong Kong became an SAR of China. Based on calculations using the Wisenews search engine, between 2000 and 2019, over this 20-year period, there have been 57 US Navy visits, including a total of 197 warships, to Hong Kong. In December 2019, in light of rising US-China tensions and the enactment of Human Rights and Democracy Act, China suspended US Navy visits to Hong Kong (BBC News, 2019, December 2). Such visits can be considered as contributing to conflict between the US and China. In Macau, however, no record of US Navy visits can be found

During the Second World War, Denmark was occupied by Germany. The Danish ambassador to the US and the Danish administration in Greenland represented the Danish government by allowing the US to protect and establish a military presence on the island. Due to Greenland's geographical advantages as a midway point between the US and Europe, the US established the Thule Air Base in North Greenland. With connections to Copenhagen reestablished in 1945, the US and Denmark formally entered into a defense agreement in return for utilizing Greenlandic territory for defensive purposes (Sørensen, 2007). The US military remains present in Greenland, and Thule Air Base is important for strategic air command and early warning systems. There has been recent discussion in the US about the need for an increased presence in Greenland in response to growing challenges arising from Russian and Chinese activities in the Arctic. The military value of the Faroe Islands for the US is clearly more limited due to its small size and less strategic location.

\section{Diplomatic interests}

The final factor to be considered is diplomatic reputation. Table 3 compares the number of officially recognized representatives. As an international financial center, Hong Kong hosts 125 consulates and recognized representatives, covering 119 countries and regions, while it has 30 recognized representative offices overseas. In Macau, there are only 15 consulates, covering 13 countries, and Macau operates just 5 recognized representative offices overseas. 77 countries have set up 'shared' consulates under the name of 'Hong Kong and Macau' and located in Hong Kong. The US Consulate General in Hong Kong and Macau is, for example, located in Hong Kong but nominally serves both cities.

Greenland and the Faroe Islands possess a similar number of consulates (13 and 12 respectively) and recognized representative offices overseas (4 and 6 respectively). In recent years, China and the US have competed on setting up consulates in the Nordic region and in turn invited them to establish representation offices. Currently, the US State Department is hiring staff for a Greenland consulate (Artic Today, 2019, November 4), while the Greenland Representation in Washington was officially inaugurated in September 2014. There is no Consulate of China in Greenland, but it has been reported that Greenland plans to open a representative office in Beijing to boost trade connections (Artic Today, 2018, July 18). In comparison, neither the US and China has a consulate or overseas office in the Faroe Islands, though a Faroese representative office opened in Beijing in August 2019 (FaroeIslands.Fo, 2019). The US thus seems more active in extending its influence in Greenland than in the Faroe Islands. 
Table 3. Number of officially recognized representatives.

\begin{tabular}{lllll}
\hline & Hong Kong & Macau & Greenland & Faroe \\
\hline $\begin{array}{l}\text { Number of consulates } \\
\begin{array}{l}\text { Number of } \\
\text { countries/regions }\end{array}\end{array}$ & 125 & 15 & 13 & 12 \\
$\begin{array}{l}\text { covered } \\
\begin{array}{l}\text { Number of overseas } \\
\text { representative offices }\end{array}\end{array}$ & 30 & 13 & 15 & 12 \\
\hline
\end{tabular}

Sources: Protocol Division Government Secretariat, HKSAR (2019); Protocol, Public Relations and External Affairs Office, MSAR (2019); Naalakkersuisut (2019); and the Government of the Faroe Islands (2019). *Consulates include Consulates-General, Honorary Consulate, and officially recognized representatives within the territories

\section{Conclusion}

Even though the importance of international linkages for island sustainability is wellrecognized, studies have largely focused on Western linkages. In the era of competition between China and the US, there is a need to reassess and refine our understanding of international linkages. With the rise of the China and China's own deployment of the BRI as a counterweight to the US-dominated world order, this paper adopts a mixed mostdifferent and most-similar case selection method to analyze the responses from four island territories. Hong Kong people are split as to whether it is necessary or desirable to be dependent on China as long as strong linkages to the Western world are an option. Although the Hong Kong government actively promotes the BRI, the community is polarized in its views of the Chinese government, which has an impact upon reception of Chinese policy initiatives. At present, societal consensus within Hong Kong seems impossible. With traditionally stronger US linkages and objections from Denmark, Greenland has faced considerable challenges to accepting the BRI. The case of Greenland evidently reflects the intervention by external states. At the other end of the spectrum, the cases of Macau and the Faroe Islands tend to demonstrate a greater willingness or ability to embrace the opportunities brought by the BRI, arguably due to their relatively weaker US presences.

Small island territories primarily remain economically and politically dependent on large states, often hoping to develop 'economic independence' over time (Dunn 2011). This approach largely rests upon an island territory perspective that underestimates the calculation of large states. Although many practices have been adopted by island territories to build international connections, large states will only accept these if they accord with their strategic interests. Overall, this article contributes to the literature on island politics by comparing internal factors (namely island sizes, types, and positions) and external factors, with a geopolitical perspective in the era of China's rise in global politics. The findings of this article suggest that island territories with strong US linkages (or US interests) tend to enjoy a lower degree of internal and external autonomy, which results in more challenges when it comes to accepting the BRI. In contrast, island territories with weak US linkages tend to hold a higher degree of autonomy and fewer challenges when it comes to seizing the opportunities provided by the BRI. 
Given the scope of this article, we have not discussed the avenues through which these international factors translate into different outcomes in BRI involvement. For example, does a stronger US presence result in stronger resistance to the BRI due to high-level diplomatic pressure, the development of a stronger civil society, or a more liberal-minded population? Such causal mechanisms are promising avenues for future research. Also, this paper is composed of two island territories in Asia and two that are affiliated with a European country. Future studies should test the hypothesis with island cases from, for example, the Indian Ocean or the Caribbean.

\section{References}

Adler-Nissen, R. (2014). The Faroe Islands: Independence dreams, globalist separatism and the Europeanization of postcolonial home rule. Cooperation and Conflict, 49(1), 55-79. https://doi.org/10.1177/0010836713514150

Alberti, F., \& Goujon, M. (2020). A composite index of formal sovereignty for small islands and coastal territories. Island Studies Journal, 15(1), 3-24. https://doi.org/10.24043/isj.96

Amoamo, M. (2013). Development on the periphery: A case study of the sub-national island jurisdiction of Pitcairn Island. Asia Pacific Viewpoint, 54(1), 91-108. https://doi.org/10.1111/apv.12006

Anckar, C. (2008). On the applicability of the most similar systems design and the most different systems design in comparative research. International Journal of Social Research Methodology, 11(5), 389-401. https://doi.org/10.1080/13645570701401552

Andersson, P., Willaing, J., \& Kalvig, P. (2018). Chinese mining in Greenland: Arctic access or access to minerals? Arctic Yearbook, 2018, 1-15.

Arctic Today (2019, November 4). The US State Department is now hiring for a Greenland consulate. Arctic Today. Retrieved from: https://www.arctictoday.com/the-us-statedepartment-is-now-hiring-for-a-greenland-consulate/

Arctic Today (2018, July 18). Greenland plans to open a Beijing office to boost trade ties with China. Arctic Today. Retrieved from: https://www.arctictoday.com/greenland-plansopen-beijing-office-boost-trade-ties-china/

Armstrong, H.W., \& Read, R. (2003). The determinants of economic growth in small states. The Round Table, 92(368), 99-124. https://doi.org/10.1080/00358530309635

Armstrong, H.W., \& Read, R. (2000). Comparing the economic performance and dependent territories and sovereign microstates. Economic Development and Cultural Change, 48(2), 285-306. https://doi.org/10.1086/452459

Bader, J. (2015). China, autocratic patron? An empirical investigation of China as a factor in autocratic survival. International Studies Quarterly, 59(1), 23-33. https://doi.org/10.1111/isqu.12148

Baldacchino, G. (2020). How far can one go? How distance matters in island development. Island Studies Journal, 15(1), 25-42. https://doi.org/10.24043/isj.70

Baldacchino, G., \& Milne, D. (2000). Lessons from the political economy of small islands: The resourcefulness of jurisdiction. Macmillan. 
BBC News (2019, December 2). China suspends US Navy visits to Hong Kong over support for protests. BBC. Retrieved from: https://www.bbc.com/news/world-asia-china$\underline{50626796}$

Bennett, A. (2012). Case study methods: Design, use, and comparative advantages. In D.F. Sprinz \& Y. Wolinsky-Nahmias (Eds.). Models, numbers, and cases methods for studying international relations (pp. 19-55). University of Michigan Press.

Bertram, I.G., \& Watters, R.F. (1985). The MIRAB economy in South Pacific microstates. Pacific Viewpoint, 26(3), 497-519. https://doi.org/10.1111/apv.263002

Blaxekær, L.Ø., Lanteigne, M., \& Shi, M.M. (2018). The Polar Silk Road \& the West Nordic Region. Arctic Yearbook, 2018, 1-19.

Belt and Road Initiative - Hong Kong (2019). HKSARG's work on the Belt and Road. Belt and Road Initiative - Hong Kong. Retrieved from: https://www.beltandroad.gov.hk/work.html.

Bueger, C., \& Wivel, A. (2018). How do small island states maximize influence? Creole diplomacy and the smart state foreign policy of the Seychelles. Journal of the Indian Ocean Region, 14(2), 170-188. https://doi.org/10.1080/19480881.2018.1471122

Campling, L. (2006). A critical political economy of the small island developing states concept South-South cooperation for island citizens?. Journal of Developing Societies, 22(3), 235285. https://doi.org/10.1177/0169796x06068031

Census and Statistics Department of Hong Kong (2019). Hong Kong in figures. Census and Statistics Department of Hong Kong. Retrieved from: https://www.censtatd.gov.hk/hkstat/hkif/index.jsp

Cooper, A.F., \& Shaw, T.M. (2009). The diplomacies of small states at the start of the twentyfirst century: How vulnerable? How resilient? In A.F. Cooper \& T.M. Shaw (Eds.). The diplomacies of small states between vulnerability and resilience (pp. 1-18). Palgrave Macmillan.

Corbett, J. (2020). Territory, islandness, and the secessionist imaginary: Why do very small communities favour autonomy over integration? Nations and Nationalism, Epub ahead of print. https://doi.org/10.1111/nana.12597

Davis, S., Munger, L.A., \& Legacy H.J. (2020). Someone else's chain, someone else's road: U.S. military strategy, China's Belt and Road Initiative, and island agency in the Pacific. Island Studies Journal, 15(2), 13-36. https://doi.org/10.24043/isj.104

Dornan, M., \& Pryke, J. (2017). Foreign aid to the Pacific: Trends and developments in the twenty-first century. Asia \& The Pacific Policy Studies, 4(3), 386-404. https://doi.org/10.1002/app5.185

Dunn, L. (2011). The impact of political dependence on small island jurisdictions. World Development, 39(12), 2132-2146. https://doi.org/10.1016/j.worlddev.2011.04.002

Faroe Islands.FO (2019). Facts and figures. Retrieved from: https://www.faroeislands.fo/thebig-picture/facts-and-figures/

FaroeIslands.FO (2019). Faroese representation to open in Beijing. FaroeIslands.Fo. Retrieved from: https://www.faroeislands.fo/the-big-picture/news/faroese-representation-toopen-in-beijing/

Ferdinand. P. (2016). Westward ho: The China dream and 'One Belt, One Road': Chinese foreign policy under $\mathrm{Xi}$ Jinping. International Affairs, 92(4), 941-957. https://doi.org/10.1111/1468-2346.12660 
Ferdinand, M., Oostindie, G., \& Veenendaal, W. (2020). A global comparison of nonsovereign island territories: The search for 'true equality'. Island Studies Journal, 15(1), 43-66. https://doi.org/10.24043/isj.75

Fish, M., \& Gunther, W.D. (1994). Small island economies, tourism, and political crises. In D.L. McKee (Ed.). External linkages and growth small economies (pp. 81-90). Praeger.

Fong, B.C.H. (2013). State-society conflicts under Hong Kong's hybrid regime: Governing coalition building and civil society challenges. Asian Survey, 53(5), 854-882. https://doi.org/10.1525/as.2013.53.5.854

Fullerton, J. (2019, December 11). Chinese ambassador 'threatens to withdraw trade deal with Faroe Islands' in Huawei $5 \mathrm{G}$ row. The Telegraph. Retrieved from: https://www.telegraph.co.uk/news/2019/12/11/chinese-ambassador-threatenswithdraw-trade-deal-faroe-islands/

Gad, U.P. (2017). National identity politics and postcolonial sovereignty games: Greenland, Denmark, and the European Union. Museum Tusculanum Press.

Gad, U.P. (2014). Greenland: A post-Danish sovereign nation state in the making. Cooperation and Conflict, 49(1), 99-118. https://doi.org/10.1177/0010836713514151

Gad, U.P., Graugaard, N.D., Holgersen, A., Jacobsen, M., Lave, N., \& Schriver, N. (2018). Imagining China on Greenland's road to independence. Arctic Yearbook, 2018, 1-22.

Garrett, D. (2014). Superheroes in Hong Kong's political resistance: Icons, images, and opposition. PS: Political Science and Politics, 47(1), 112-119. https://doi.org/10.1017/s1049096513001637

Government of the Faroe Islands (2019). Faroese representatives. Government of the Faroe Islands. Retrieved from: https://www.government.fo/

Grydehøj, A. (2020a). Critical approaches to island geography. Area, 52(1), 2-5.

Grydehøj, A. (2020b). Government, Policies, and Priorities in Kalaallit Nunaat (Greenland): Roads to Independence. In K. Coates \& C. Holroyd (Eds.). The Palgrave handbook of Arctic policy and politics (pp. 217-231). Palgrave Macmillan.

Grydehøj, A. (2020c). Unraveling economic dependence and independence in relation to island sovereignty: The case of Kalaallit Nunaat (Greenland). Island Studies Journal, 15(1), 89-112. https://doi.org/10.24043/isj.101

Grydehøj, A. (2015). Island city formation and urban island studies. Area, 47(4), 429-435. https://doi.org/10.1111/area.12207

Hay, P. (2006). A phenomenology of islands. Island Studies Journal, 1(1), 19-42.

HKSAR Government (2019). Hong Kong Human Rights and Democracy Act. Hong Kong SAR Government. Retrieved from: https://www.info.gov.hk/gia/general/201911/20/P2019112000582.htm.

HKUPOP (2019a). Hong Kong people's confidence in China's future - half-yearly average. Public Opinion Program, The University of Hong Kong. Retrieved from: https://www.hkupop.hku.hk/chinese/popexpress/trust/conchifuture/halfyr/chi half yr chart.html

HKUPOP (2019b). Macau people's confidence in China's future. Public Opinion Program, The University of Hong Kong. Retrieved from: https://www.hkupop.hku.hk/chinese/popexpress/macau/conChiFuture/datatables.html 
Hong Kong Institute of Asia-Pacific Studies (2016). Survey on the BRI. Hong Kong Institute of Asia-Pacific Studies. Retrieved from: http://www.hkiaps.cuhk.edu.hk/wd/ni/20170612-114255 1.pdf

Hook, B., \& Neves, M.S. (2002). The role of Hong Kong and Macau in China's relations with Europe. The China Quarterly, 169, 108-135. https://doi.org/10.1017/s0009443902000086

Inman, P. (2019, August 19). Why does Donald Trump want to buy Greenland?. The Guardian. Retrieved from: https://www.theguardian.com/usnews/2019/aug/19/why-does-donald-trump-want-to-buy-greenland

Jackson, R.E. (2008). Islands on the edge: Exploring islandness and development in four Australian cases studies (Doctoral thesis, University of Tasmania, Australia). Retrieved from https://core.ac.uk/download/pdf/33312326.pdf

Jesse, N.G., \& Dreyer, J.R. (2016). Small states in the international system at peace and war. Lexington Books.

Karlsson, A. (2009). Sub-national island jurisdictions as configurations of jurisdictional powers and economic capacity: Nordic experiences from Åland, Faroes and Greenland. Island Studies Journal, 4(2), 139-162. https://doi.org/10.1163/15718115-02403004

Kwong, Y.H. (2016). State-society conflict radicalization in Hong Kong: The rise of 'antiChina' sentiment and radical localism. Asian Affairs, 47(3), 428-442. https://doi.org/10.1080/03068374.2016.1225897

Kwong, Y.H., \& Wong, M.Y.H. (2017). State size and democratization in hybrid regimes: the Chinese island cities of Macau and Hong Kong. Island Studies Journal, 12(2), 113126. https://doi.org/10.24043/isj.36

Lee, D., \& Smith, N.J. (2010). Small state discourses in the international political economy. Third World Quarterly 31(7), 1091-1105. https://doi.org/10.1080/01436597.2010.518750

Lee, F.L.F., Yuen, S., Tang, G., \& Cheng, E.W. (2019). Hong Kong's summer of uprising: From anti-extradition to anti-authoritarian protests. China Review, 19(4), 1-32.

Levine, S. (2012). The experience of sovereignty in the Pacific: Island states and political autonomy in the twenty-first century. Commonwealth \& Comparative Politics, 50(4), 439455. https://doi.org/10.1080/14662043.2012.729729

Liu, H., \& Lim, G. (2019). The political economy of a rising China in Southeast Asia: Malaysia's response to the Belt and Road Initiative. Journal of Contemporary China, 28(116), 216-231. https://doi.org/10.1080/10670564.2018.1511393

Ma, N. (2015). The rise of 'Anti-China' sentiments in Hong Kong and the 2012 Legislative Council elections. China Review, 15(1), 39-66.

Macau SAR Government (2019). Supporting Macau to contribute to BRI. Macau SAR Government. Retrieved from: https://www.gov.mo/zh-hant/content/272645-2/

Macau Statistics and Census Services (2019). Yearbook of statistics 2018. Macau Statistics and Census Services.

McBride, K. (2019). Sailing towards digitalization when it doesn't make cents? Analysing the Faroe Islands' new digital governance trajectory. Island Studies Journal, 14(2), 193-214. https://doi.org/10.24043/isj. 93 
Naalakkersuisut (2019). Consulates in Greenland. Naalakkersuisut. Retrieved from: https://naalakkersuisut.gl/en/Naalakkersuisut/Departments/Udenrigsanliggende/Kon sulater-i-Groenland

Oest, K.J.N., \& Wivel, A. (2010). Security, profit or shadow of the past? Explaining the security strategies of microstates. Cambridge Review of International Affairs, 23(3), 429453. https://doi.org/10.1080/09557571.2010.484047

Penrose, J. (2002). Nations, states and homelands: Territory and territoriality in nationalist thought. Nations and Nationalism, 8(3), 277-297. https://doi.org/10.1111/1469$\underline{8219.00051}$

Peterson, J.E. (2006). Qatar and the world: Branding for a micro-state. Middle East Journal, 60(4), 732-748. https://doi.org/10.3751/60.4.15

Prasad, N. (2003). Small islands' quest for economic development. Asia Pacific Development Journal, 10(1), 47-67. https://doi.org/10.18356/0ccf15f2-en

Protocol Division Government Secretariat, HKSAR (2019). Consular posts and officially recognized bodies. Protocol Division Government Secretariat, HKSAR. Retrieved from: https://www.protocol.gov.hk/eng/consular/index.html\#

Protocol, Public Relations and External Affairs Office, MSAR. (2019). Consular affairs. Protocol, Public Relations and External Affairs Office, MSAR. Retrieved from: https://www.gprpae.gov.mo/consular/ConsularAffairs.html.

Pöllath, M. (2018). Revisiting island decolonization: The pursuit of self-government in Pacific island politics under US hegemony. Island Studies Journal, 13(1), 235-250. https://doi.org/10.24043/isj.46

Satarino, A. (2019, December 20). At the edge of the world a new battleground for the U.S. and China. The New York Times. Retrieved from: https://www.nytimes.com/2019/12/20/technology/faroe-islands-huawei-china-us.html

Seawright, J., \& Gerring, J. (2008). Case selection techniques in case study research: A menu of qualitative and quantitative options. Political Research Quarterly, 61(2), 294-308. https://doi.org/10.1177/1065912907313077

Statistics Faroe Islands (2019). Export of goods by fish species and other groups, country of final destination. Statistics Faroe Islands. Retrieved from: https://statbank.hagstova.fo/pxweb/en/H2/H2 UH UH01/uh utfisk t.px/table/ tableViewLayout2/

Statistics Greenland (2019). Greenland in figures 2019. Statistics Greenland. Retrieved from: http://www.stat.gl/publ/en/GF/2019/pdf/Greenland\%20in\%20Figures\%202019.pdf

Sørensen, A K. (2007). Denmark-Greenland in the twentieth century. Museum Tusculanum Press.

Tekdal, V. (2018). China's Belt and Road Initiative: At the crossroads of challenges and ambitions. The Pacific Review, 31(3), 373-390. https://doi.org/10.1080/09512748.2017.1391864

Tillman, H., Yang, J., \& Nielsson, E.T. (2018). The Polar Silk Road: China's new frontier of international cooperation. China Quarterly of International Strategic Studies, 4(3), 345362. https://doi.org/10.1142/s2377740018500215

US Congress (1992). US-Hong Kong Policy Act. US Congress. Retrieved from: https://uscode.house.gov/view.xhtml?path=/prelim@title22/chapter66\&edition=prelim 
US Department of State (2004). US-Macau Policy Act Report. US Department of State. Retrieved from: https://2001-2009.state.gov/p/eap/rls/rpt/4048.htm\#preface.

US Embassy in Denmark (2019). US \& Faroe Islands. US Embassy in Denmark. Retrieved from: https://dk.usembassy.gov/our-relationship/u-s-faroe-islands/

Warrington, E., \& Milne, D. (2007). Governance \& jurisdiction. In G. Baldacchino (Ed.). A world of islands: An island studies reader (pp. 379-427). Island Studies Press.

Wong, M. Y. H. (2019). Chinese influence, U.S. linkages, or neither? Comparing regime changes in Myanmar and Thailand. Democratization, 26(3), 359-381. https://doi.org/10.1080/13510347.2018.1534098

Veenendaal, W.P. (2017). Analyzing the foreign policy of microstates: The relevance of the international patron-client model. Foreign Policy Analysis 13(3), 561-577. https://doi.org/10.1111/fpa.12068

Xinhua (2017, March 16). Report on the work of the government. Xinhua. Retrieved from: http://english.www.gov.cn/premier/news/2017/03/16/content 281475597911192.htm

$\mathrm{Yu}$, H. (2018). Motivation behind China's 'One Belt, One Road' initiatives and establishment of the Asian Infrastructure Investment Bank. Journal of Contemporary China, 26(105), 353-368. https://doi.org/10.4324/9780429317002-2

Yuen, S., \& Cheng, E.W. (2020). Between high autonomy and sovereign control in a subnational island jurisdiction: The paradox of Hong Kong under 'One Country, Two Systems'. Island Studies Journal, 15(1), 131-150. https://doi.org/10.24043/isj.110 
Ying-ho Kwong \& Mathew Y. H. Wong 